\title{
TSP, PM10 and PM2.5 Distribution Characteristics in the Thermal Power Plants in Korea
}

\author{
Geum-Ju Song*, Young-Hoon Moon, Jong-Ho Joo, A-Yeoung Lee, Jae-Bok Lee \\ Institute of Environmental and Energy Technology, Pohang University of Science and Technology (POSTECH), Pohang, Republic of Korea
}

Email address:

gjsong@postech.ac.kr (Geum-Ju S.)

${ }^{*}$ Corresponding author

\section{To cite this article:}

Geum-Ju Song, Young-Hoon Moon, Jong-Ho Joo, A-Yeoung Lee, Jae-Bok Lee. TSP, PM10 and PM2.5 Distribution Characteristics in the Thermal Power Plants in Korea. International Journal of Economy, Energy and Environment. Vol. 4, No. 4, 2019, pp. 63-70. doi: $10.11648 /$ j.ijeee.20190404.11

Received: April 12, 2019; Accepted: May 31, 2019; Published: August 10, 2019

\begin{abstract}
In this study, the emission characteristics and heavy metal contents of TSP, PM10 and PM2.5 pollutants from three thermal power plants in Korea were investigated and compared to the electric production capacity, type of fuel and sort of air-pollution-control device. For the measurement and analysis, Korean standard test method US EPA method were used. The average concentration of TSP, PM10 and PM2.5 emitted from Plant A were 7.39, 6.16, $4.83 \mathrm{mg} / \mathrm{Sm}^{3}$, Plant B was 5.82, 4.87, $2.35 \mathrm{mg} / \mathrm{Sm}^{3}$ and Plant $\mathrm{C}$ was $1.54,1.40,10.02 \mathrm{mg} / \mathrm{Sm}^{3}$, respectively. Plant A that uses heavy oil as the main fuel showed higher TSP, PM10 and PM2.5 than Plant B that uses mostly anthracite coal, and plant B showed higher TSP, PM10 and PM2.5 than Plant $\mathrm{C}$ that mainly uses bituminous coal. The concentration of fine particles decreased as electricity-production capacity increased. The fractions of PM10 and PM2.5 in TSP were relatively high in tested plants; this result means that more fine particles than coarse particles were emitted from all stacks. The distribution of heavy metals by particle size showed similar trends in all plants. The concentration of $\mathrm{Zn}$ and $\mathrm{Mn}$ in TSP, PM10 and PM2.5 showed higher than the others in all plants. These results confirm that the content of heavy metals in the particulate matter is influenced by the fuel that the plant uses.
\end{abstract}

Keywords: Emission, TSP, PM10, PM2.5, Fuel, Heavy Metals, Thermal Power Plant

\section{Introduction}

Atmospheric pollutants can directly or indirectly harm human health and properties, and ecosystems. These air pollutants are classified into Criteria Air Pollutants (CAPs) and Hazardous Air Pollutants (HAPs) [1]. These substances can be emitted by natural events such as volcanic eruptions, forest fires and outgassing from swamps, or by human technologies such as static facilities or vehicles.

Particulate pollutants are generated by mechanical treatment such as crushing and sorting of a substance, or by combustion and decomposition processes. Fine particles include secondary dusts such as fume, soot, carbon black, combustion nuclides, and oxygen-containing hydrocarbons, sulfates and nitrates. Coarse particles include solid particles such as cement dust, coal dust, and liquid particles such as raindrops, sprays, and fogs.

Management of particulate pollutants has been intensified, and attention has been focused on the effects of particle size and of the components that constitute each particle. In 1983, criteria for Total Suspended Particulates (TSPs) were introduced in Korea. In 1995, the air environment standard for the particulate matter of diameter $\leq 10 \mu \mathrm{m}$ (Particulate Matter 10, PM10) was strengthened (to an average of $100 \mu \mathrm{g} / \mathrm{m}^{3}$ for $24 \mathrm{~h}$; average of $50 \mu \mathrm{g} / \mathrm{m}^{3}$ for a year). From 2015, Korea has begun to manage particles with diameters $\leq 2.5 \mu \mathrm{m}$ (Particulate Matter 2.5, PM2.5), and the management standard is based on an average of $50 \mu \mathrm{g} / \mathrm{m}^{3}$ for $24 \mathrm{~h}$ or an average of 25 $\mu \mathrm{g} / \mathrm{m}^{3}$ for a year [1]. According to data collected in $2014,91.8 \%$ of the 255 measurement sites in the nation exceeded the 24-h average and $38.8 \%$ exceeded the PM10 annual average [2]. The average annual concentration of PM2.5 in the six major cities in Korea in the last three years has been $32 \mu \mathrm{g} / \mathrm{m}^{3}$ (28-39 $\left.\mu \mathrm{g} / \mathrm{m}^{3}\right)$, which exceeds the US standard $\left(12 \mu \mathrm{g} / \mathrm{m}^{3}\right)$ [3] and the 
European standard $\left(25 \mu \mathrm{g} / \mathrm{m}^{3}\right)$ [4], and is about three times the level of $10 \mu \mathrm{g} / \mathrm{m}^{3}$ recommended by WHO [5]. Studies on human effects on PM10 have reported an increase in mortality of about $0.5 \%$ per $10 \mu \mathrm{g} / \mathrm{m}^{3}$ of PM10 [6-7]. Based on these data, WHO recommends an annual average concentration of PM10 of $20 \mu \mathrm{g} / \mathrm{m}^{3}$, and a 24-h average concentration of 50 $\mu \mathrm{g} / \mathrm{m}^{3}$ for short-term exposure. Because of its small size, PM2.5 is not filtered by the bronchi, and weakens pulmonary function or causes cardiovascular diseases [8]. Long-term exposure to PM2.5 concentration of $11 \sim 15 \mu \mathrm{g} / \mathrm{m}^{3}$ has associated risks, so WHO recommends an annual average of $10 \mu \mathrm{g} / \mathrm{m}^{3}$ [9-11].

In Korea, the necessity of managing PM2.5 emerged in the 1990 s, as patients with respiratory-related diseases and those with cardiovascular-related diseases died early due to the effects of PM2.5 inhalation [12]. To avoid these consequences, the sources of PM2.5 must be identified, and plans to reduce their emissions must be developed. According to the domestic air pollutant emission data in 2014, total TSP emission amount is about 147 ton/y, PM10 about 98 ton/y and PM2.5 about 63 ton/y. Point sources of pollution emit $63-83 \%$ TSP, $17-36 \%$ PM10 and 0.2 - 0.7\% PM2.5 [13].

Among point sources, manufacturing combustion processes emit the highest levels of TSP, PM10, and PM2.5. However, combustion facilities of the energy-generation industry emit TSP that have larger proportions of PM10 or PM2.5 than do combustion facilities of manufacturing processes. Therefore, production of fine dust should be managed in combustion facilities of the energy-generation industry sources. Pollutants generated during coal combustion especially particulate matter below PM10, can harm human health [14-16]. These pollutants are particularly problematic in developing countries, where dust from coal combustion accounts for one-third of the total amount of dust generated [17].

In September 2017, the Korean government announced the "Plan for Fine Dust Management" jointly with the related ministries to plan detailed implementation of measures to reduce fine dust emission from old coal-fired power plants. The highest priority is to replace or upgrade the facilities to reduce production of fine dust by coal-fired power plants. The first step toward meeting this goal is to accurately measure and characterize the particulate and particulate precursors generated by the current operating facility. Also, the components of fine dusts must be identified. Many existing studies have stated that harmful heavy metals in fine dusts can exacerbate affect respiratory diseases and cardiovascular diseases [18].

Therefore, in this study, emission characteristics and constituents of TSP, PM10 and PM2.5 were investigated in three operating thermal power plants in Korea. The plants were selected to have different electric production capacity, fuel and sort of the air pollution control devices; the distributions of fine particle and contents of heavy metals in fine particles were investigated according these differences.

\section{Methods and Materials}

\subsection{Target Plants}

Generally, a thermal power plant burns by injecting fuel with air into the boiler. A selective catalytic reduction system (SCR) or a nonselective catalytic reduction system (SNCR) is used to reduce the concentration of NOx in the emitted combustion gases. An electrostatic precipitator (ESP) or a fabric filter (FF) is used to remove dust. A flue-gas desulfurization system (FGD) is used to remove SOx.

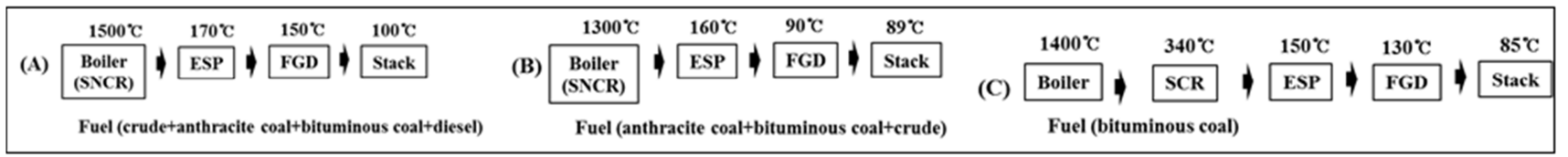

Figure 1. Process and condition of each plant tested.

In this study, three thermal power plants with different capacity and used fuel were selected as target plants (Figure 1). Plant A has a capacity of $20 \mathrm{MW} / \mathrm{h}$ and uses heavy oil as the main fuel $(33603 \mathrm{~L} / \mathrm{d})$, with 724 ton/d of anthracite coal, 1384 ton/d of bituminous coal and $1275 \mathrm{~L} / \mathrm{d}$ of diesel as sub-fuels. Plant B has capacity of $200 \mathrm{MW} / \mathrm{h}$ and uses anthracite coal as the main fuel (975 ton/d), with 244 ton/d of bituminous coal and $137 \mathrm{~L} / \mathrm{d}$ of heavy oil as sub-fuels. Plant $\mathrm{C}$ has a capacity of $500 \mathrm{MW} / \mathrm{h}$ and uses bituminous coal as the only fuel (4993 ton/d). Plant A and B used SNCRs. Plant C had a separate denitrification facility (SCR).

\subsection{Sampling Method}

PM10 and PM2.5 were sampled (Figure 2) in accordance with the air pollution test standard "ES 01112.1 - Method of collecting particulate matter of exhaust gas" [19] and "ES 01317.1 - Method of collecting fine dust (PM10 and PM2.5)"
[20]. The test method is applicable only when the temperature of the final exhaust gas is $\leq 260^{\circ} \mathrm{C}$, and should satisfy constant velocity suction coefficient of $90-110 \%$. The PM10 and PM2.5 are removed from TSP by a cyclone combination unit, then collected using a nozzle directly in front of the filter holder. The PM10 cyclone had cut diameter $(\mathrm{D} 50)=9-11 \mu \mathrm{m}$, and the PM2.5 cyclone had D50 - $2.25-$ $2.27 \mu \mathrm{m}$. The sampling rate was varied according to the exhaust gas temperature. In this case, a nozzle capable of collecting particles within the range of D50 should be used [21]. Sampling was performed three times in the stack that is the final outlet of each plant. The sample was collected using a circular quartz filter which was heated at $500^{\circ} \mathrm{C}$ for $2-3 \mathrm{~h}$. The samples volumes were $>2 \mathrm{Sm}^{3}$, but differed slightly depending on the temperature, the dynamic pressure and the static pressure of the exhaust gas of each plant. 


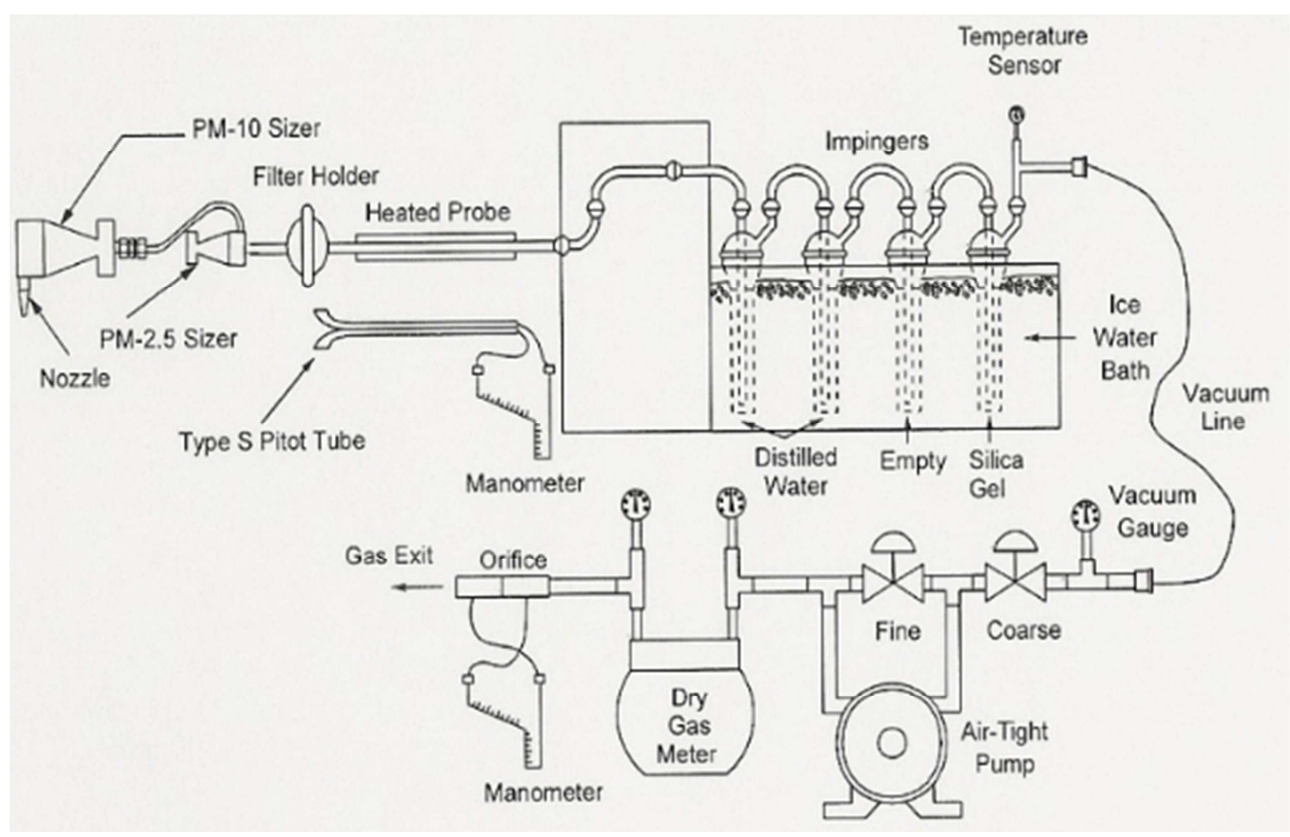

Figure 2. Sampling train for TSP, PM10 and PM2.5 in the stack.

\subsection{TSP, PM10, PM2.5 Concentration Calculation and Heavy Metal Analysis Method}

\subsubsection{TSP, PM10, PM2.5 Concentration Calculation Method}

The filter holder (figure 2) was placed in a quartz filter, samples were collected, and the filters were stored in individual filter cases for transport to the laboratory. In the laboratory, the moisture was removed and the weight concentration of particulates was determined using a balance (model: METER MT, UMT) that can measure with a precision of $10^{-4} \mathrm{~g}$. The dust concentration in the exhaust gas was calculated by dividing the weight concentration by the sampled volume of gas.

\subsubsection{TSP, PM10, PM2.5 Heavy Metal Analysis Method}

The investigated target compounds were $\mathrm{Cd}, \mathrm{Cr}, \mathrm{Cu}, \mathrm{Mn}, \mathrm{Ni}$, $\mathrm{Pb}, \mathrm{V}$ and $\mathrm{Zn}$. Most of these have emission standard values $\left[\mathrm{mg} / \mathrm{Sm}^{3}\right]$ : $\mathrm{Cd}, 0.02 ; \mathrm{Cr}, 0.3 ; \mathrm{Cu}, 5 ; \mathrm{Ni}, 2 ; \mathrm{Pb}, 0.2$ and $\mathrm{Zn}: 5$ [22]. $\mathrm{Mn}$ and $\mathrm{V}$ in particulate matter have no emission standard yet, but they are abundant in coal and heavy oil. For the analysis of the target compounds in the collected particulate matter, EPA method 3051A [23] was used. In the pretreatment method, $10 \mathrm{~mL}$ of nitric acid was injected into a microwave sample pretreatment apparatus (model: MARS, CEM), and about $15 \mathrm{~mL}$ of distilled water was added so that the filter was immersed. The vessel was placed in a hood to remove the generated gas, then disassembled using a microwave sample pretreatment apparatus. The dissolved sample was filtered through filter paper (Whatman No. 41), then the sample solution was prepared by adding the sample to a $50-\mathrm{mL}$ volumetric flask that was then filled to the mark with distilled water. The target compounds were analyzed using Inductively Coupled Atomic Emission Spectrometer (820-MS, Varian). A standard heavy-metal stock from Accustandard was used for heavy-metal analysis. The standard solution was prepared by diluting a standard stock solution of $1000 \mathrm{mg} / \mathrm{L}$ to $1,3,5,10$, or $20 \mu \mathrm{g} / \mathrm{L}$, and adjusting the nitric acid concentration to $1 \%$. Samples were analyzed according to EPA 200.89 [24]. A rinse blank was used between samples. The accuracy and precision experiments the methods were performed according to the QA/QC Handbook [25]. The accuracy was $80-90 \%$, which is sufficient. The precision was $2.6-16.9 \%$, which is less than the tolerable range of $20 \%$, so the reproducibility in the experiment is confirmed. The calibration curves of target compounds all had coefficients of determination $\left(r^{2}\right)>0.9998$. The linear range of the calibration curve was used to check the stability of the instrument and the conditions.

\section{Results and Discussion}

\subsection{Concentration of TSP, PM10 and PM2.5}

The concentration and fraction of TSP, PM10 and PM2.5 were calculated for each plant (Table 1). Generally, the TSP is calibrated to $6 \%$ oxygen for power plants that use solid fuels or liquid fuels [22]. However, in this study, the measured values are presented without oxygen correction to facilitate comparison of PM10 and PM2.5.

Plant A had TSP $=4.62-9.78$ (7.39 avg.) $\mathrm{mg} / \mathrm{Sm}^{3}, \mathrm{PM} 10$ $=5.02-8.35$ (6.16 avg.) $\mathrm{mg} / \mathrm{Sm}^{3}$ and PM $2.5=3.16-6.71$ (4.83 avg.) $\mathrm{mg} / \mathrm{Sm}^{3}$. The fraction of PM10 in TSP was $\sim 83 \%$, the fraction of PM2.5 in TSP was $\sim 65 \%$, and the fraction of PM2.5 in PM10 was $78 \%$.

Plant B had TSP $=5.43-6.11$ (5.82 avg.) $\mathrm{mg} / \mathrm{Sm}^{3}$, PM10 $=4.45-5.40$ (4.87avg.) $\mathrm{mg} / \mathrm{Sm}^{3}$ and PM2.5 = $2.03-2.80$ (2.35avg.) $\mathrm{mg} / \mathrm{Sm}^{3}$. The fraction of PM10 in TSP was $\sim 84 \%$, the fraction of PM2.5 in TSP was $\sim 40 \%$, and the fraction of PM2.5 in PM10 was $\sim 48 \%$. 
Plant $\mathrm{C}$ had TSP $=1.46-1.60$ (1.54 avg.) $\mathrm{mg} / \mathrm{Sm}^{3}, \mathrm{PM} 10$ $=1.31-1.57$ (1.40 avg.) $\mathrm{mg} / \mathrm{Sm}^{3}$ and $\mathrm{PM} 2.5=0.96-1.13$ (1.02 avg.) $\mathrm{mg} / \mathrm{Sm}^{3}$. The fraction of PM10 in TSP was $\sim 90 \%$, the fraction of PM2.5 in TSP was $\sim 66 \%$, and the fraction of PM2.5 in PM10 was 73\%.

The distribution of fine dust varies according to the emission plant, but also varies depending on the capacity and process of the plant and the fuel used [18]: in combustion plants that used fossil fuels, TSP was in the range of $0.7-14.4$ $\mathrm{mg} / \mathrm{Sm}^{3}$, and PM10 was $88.4-97.0 \%$, PM2.5 was $65.7-75.5 \%$ and PM10 was 25.5-52.0\%; when the fuel was anthracite coal, the fraction of PM10 and PM2.5 to TSP was somewhat low, and at all of the plants, the dust collector was equipped with an electrostatic precipitation [18]. In the present study, the highest concentration of TSP was found in Plant A that uses heavy oil. Of TSP in this plant, $83.4 \%$ was PM10 and $65.3 \%$ was PM2.5. In addition, TSP concentration was higher in Plant $\mathrm{B}$ that uses anthracite than in Plant $\mathrm{C}$ that uses bituminous coal. Of TSP in Plant B, 83.6\% was PM10 and $40.4 \%$ was PM2.5. TSP concentration in emissions was lowest from Plant C, but in it $90.2 \%$ was PM10 and $66.1 \%$ was PM2.5. This is the same trend as noted by Ehrlich et al. [18] and the same as in surveys of the fine dust emitted by domestic thermal power plants [26-29]. In addition, Ehrlich et al. [18] reported that plants that have an SNCR that inject elements for NOx treatment have higher TSP concentrations than plants that lack an SNCR. Our results agree with these.

In this study, TSP concentrations were higher for Plants A and B, which used an SNCR to remove NOx, than for Plant $\mathrm{C}$, which uses an SCR. The amount of particulate matter was highest in the plant that had the smallest. Therefore, this study demonstrated that the distribution of particle concentration and particle size are affected by the capacity and process of the plant, the type of prevention plants, and the fuel used, as suggested by Ehrlich et al. [18]. The distributions of emitted TSP, PM10 and PM2.5 also differed among the plants (figure 3). The distributions of PM10 and PM2.5 were normalized by setting TSP to $100 \%$; $~ 90 \%$ of TSP was PM10 and $\sim 66 \%$ of TSP was PM 2.5 in all three plants.

Table 1. Mean and (range) of concentration [mg/Sm ${ }^{3}$ ] and fraction [\%] of TSP, PM10 and PM2.5 in samples from each plant.

\begin{tabular}{|c|c|c|c|c|c|c|}
\hline Plant & TSP & PM10 & PM2.5 & PM10/TSP & PM2.5/TSP & PM2.5/ PM10 \\
\hline A & $\begin{array}{l}7.39 \\
(4.62-9.78)\end{array}$ & $\begin{array}{l}6.16 \\
(5.02-8.35)\end{array}$ & $\begin{array}{l}4.83 \\
(3.16-6.71)\end{array}$ & $\begin{array}{l}83.4 \\
(65.8-108.6)\end{array}$ & $\begin{array}{l}65.3 \\
(47.1-86.4)\end{array}$ & $\begin{array}{l}78.3 \\
(55.2-131.2)\end{array}$ \\
\hline B & $\begin{array}{l}5.82 \\
(5.43-6.11)\end{array}$ & $\begin{array}{l}4.87 \\
(4.45-5.40)\end{array}$ & $\begin{array}{l}2.35 \\
(2.03-2.80)\end{array}$ & $\begin{array}{l}83.6 \\
(77.8-91.1)\end{array}$ & $\begin{array}{l}40.4 \\
(34.2-51.6)\end{array}$ & $\begin{array}{l}48.3 \\
(37.5-62.9)\end{array}$ \\
\hline $\mathrm{C}$ & $\begin{array}{l}1.54 \\
(1.46-1.60)\end{array}$ & $\begin{array}{l}1.40 \\
(1.31-1.57)\end{array}$ & $\begin{array}{l}1.02 \\
(0.96-1.13)\end{array}$ & $\begin{array}{l}90.2 \\
(83.0-98.2)\end{array}$ & $\begin{array}{l}66.1 \\
(60.2-71.6)\end{array}$ & $\begin{array}{l}72.7 \\
(61.1-86.2)\end{array}$ \\
\hline
\end{tabular}

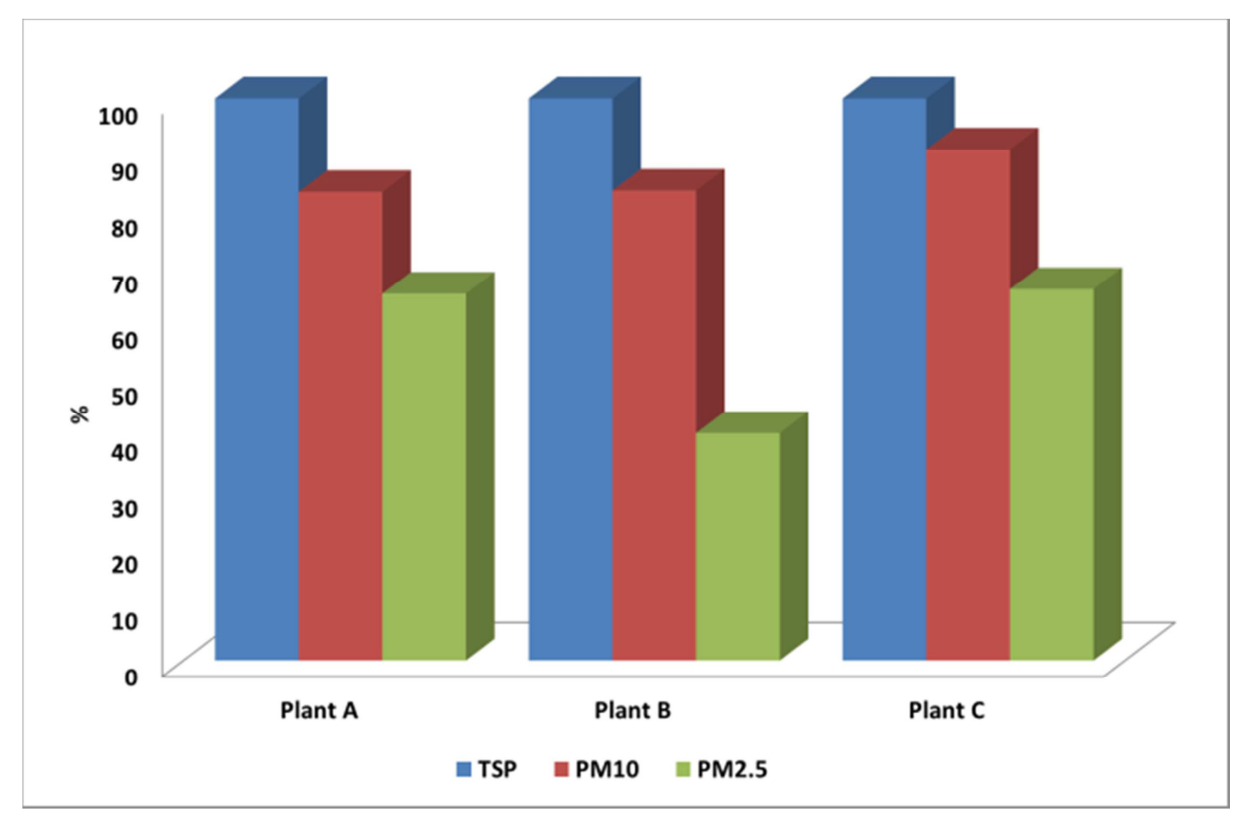

Figure 3. Distribution of TSP, PM10 and PM2.5 emitted from the stack of the tested plants.

\subsection{Concentration of Heavy Metal in TSP, PM10 and PM2.5}

\subsubsection{TSP}

The concentrations of heavy metal in TSP differed among the plants (Table 2, Figure 4). The total concentration of heavy metals in TSPs decreased in the order Plant A $>$ Plant B $>$ Plant C. The compositions were as follows: Plant $\mathrm{A}$ had $\mathrm{Zn}>$
$\mathrm{Mn}>\mathrm{Cr}>\mathrm{Pb}>\mathrm{V}>\mathrm{Ni}>\mathrm{Cu}>\mathrm{Cd}$; Plant $\mathrm{B}$ had $\mathrm{Mn}>\mathrm{Zn}>\mathrm{Ni}>$ $\mathrm{V}>\mathrm{Cu}>\mathrm{Pb}>\mathrm{Cr}$ and Plant $\mathrm{C}$ had $\mathrm{Mn}>\mathrm{Zn}>\mathrm{V}>\mathrm{Cu}>\mathrm{Ni}>$ $\mathrm{Pb}>\mathrm{Cd}>\mathrm{Cr}$. Mn, $\mathrm{V}$, and $\mathrm{Zn}$ are mainly emitted in solid fuel combustion plants, and $\mathrm{Cr}, \mathrm{Ni}$, and $\mathrm{Cu}$ are mainly emitted in liquid fuel combustion plants [30-31]. Plant $\mathrm{C}$ uses only bituminous coal as fuel; its results are similar to those of Pio et al. [30-31] and Querol et al. [32]. Plant B showed a different 
tendency, possibly because it uses solid and liquid auxiliary fuels. The higher Mn and $\mathrm{Zn}$ in Plants B and C than in Plant A were attributed to the use of coal as the main fuel; the higher $\mathrm{Pb}, \mathrm{Cr}$, and $\mathrm{Ni}$ in Plant A than in Plants $\mathrm{B}$ may occur because Plant A uses heavy oil. In addition, the higher $\mathrm{Mn}$ and $\mathrm{Zn}$ in
Plant A than in Plants B and C may be the effects of its auxiliary fuels, anthracite and bituminous coal. The difference in the content of heavy metals in the three plants seems to be due to the difference in fuel used.

Table 2. Mean and (range) of concentrations $\left[\mu \mathrm{g} / \mathrm{Sm}^{3}\right]$ of heavy metal in TSP, PM10 and PM2.5 in each plant.

\begin{tabular}{|c|c|c|c|c|c|c|c|c|c|}
\hline \multirow{2}{*}{ Plant } & \multirow{2}{*}{ Size } & \multicolumn{8}{|l|}{ Element } \\
\hline & & Cd & $\mathrm{Cr}$ & $\mathrm{Cu}$ & Mn & $\mathbf{N i}$ & $\mathbf{P b}$ & $\mathbf{V}$ & Zn \\
\hline \multirow{3}{*}{ A } & TSP & $\begin{array}{l}0.06 \\
(0.01-0.13)\end{array}$ & $\begin{array}{l}1.05 \\
(0.85-1.24)\end{array}$ & $\begin{array}{l}0.77 \\
(0.36-1.11)\end{array}$ & $\begin{array}{l}3.13 \\
(2.22-4.05)\end{array}$ & $\begin{array}{l}0.85 \\
(0.55-1.15)\end{array}$ & $\begin{array}{l}1.01 \\
(0.54-1.58)\end{array}$ & $\begin{array}{l}0.95 \\
(0.75-1.34)\end{array}$ & $\begin{array}{l}3.25 \\
(1.58-4.28)\end{array}$ \\
\hline & PM10 & $\begin{array}{l}0.03 \\
(0.02-0.03)\end{array}$ & $\begin{array}{l}1.69 \\
(0.78-2.61)\end{array}$ & $\begin{array}{l}0.59 \\
(0.46-0.79)\end{array}$ & $\begin{array}{l}3.33 \\
(2.95-4.64)\end{array}$ & $\begin{array}{l}1.55 \\
(0.82-1.99)\end{array}$ & $\begin{array}{l}0.88 \\
(0.71-1.17)\end{array}$ & $\begin{array}{l}0.95 \\
(0.77-1.34)\end{array}$ & $\begin{array}{l}3.19 \\
(1.93-3.93)\end{array}$ \\
\hline & PM2.5 & $\begin{array}{l}0.08 \\
(0.02-0.16)\end{array}$ & $\begin{array}{l}1.99 \\
(0.64-3.33)\end{array}$ & $\begin{array}{l}0.81 \\
(0.33-1.65)\end{array}$ & $\begin{array}{l}2.53 \\
(2.21-2.86)\end{array}$ & $\begin{array}{l}1.07 \\
(0.76-1.39)\end{array}$ & $\begin{array}{l}0.69 \\
(0.56-0.84)\end{array}$ & $\begin{array}{l}0.76 \\
(0.63-0.83)\end{array}$ & $\begin{array}{l}2.78 \\
(1.87-3.77)\end{array}$ \\
\hline \multirow{3}{*}{ B } & TSP & $\begin{array}{l}0.04 \\
(0.03-004)\end{array}$ & $\begin{array}{l}0.44 \\
(0.37-0.54)\end{array}$ & $\begin{array}{l}0.47 \\
(0.41-0.51)\end{array}$ & $\begin{array}{l}6.29 \\
(5.97-6.53)\end{array}$ & $\begin{array}{l}0.59 \\
(0.37-1.05)\end{array}$ & $\begin{array}{l}0.46 \\
(0.44-0.50)\end{array}$ & $\begin{array}{l}0.50 \\
(0.43-0.60)\end{array}$ & $\begin{array}{l}3.83 \\
(3.09-4.94)\end{array}$ \\
\hline & PM10 & $\begin{array}{l}0.03 \\
(0.03-0.04)\end{array}$ & $\begin{array}{l}0.25 \\
(0.16-0.30)\end{array}$ & $\begin{array}{l}0.43 \\
(0.39-0.45)\end{array}$ & $\begin{array}{l}6.06 \\
(5.65-6.48)\end{array}$ & $\begin{array}{l}0.34 \\
(0.30-0.42)\end{array}$ & $\begin{array}{l}0.44 \\
(0.41-0.51)\end{array}$ & $\begin{array}{l}0.50 \\
(0.43-0.60)\end{array}$ & $\begin{array}{l}3.56 \\
(3.27-4.08)\end{array}$ \\
\hline & PM2.5 & $\begin{array}{l}0.03 \\
(0.02-0.03)\end{array}$ & $\begin{array}{l}0.19 \\
(0.16-0.22)\end{array}$ & $\begin{array}{l}0.28 \\
(0.25-0.34)\end{array}$ & $\begin{array}{l}4.19 \\
(3.89-4.44)\end{array}$ & $\begin{array}{l}0.23 \\
(0.19-0.28)\end{array}$ & $\begin{array}{l}0.31 \\
(0.26-0.35)\end{array}$ & $\begin{array}{l}0.32 \\
(0.26-0.39)\end{array}$ & $\begin{array}{l}3.50 \\
(1.60-5.37)\end{array}$ \\
\hline \multirow{3}{*}{$\mathrm{C}$} & TSP & $\begin{array}{l}0.01 \\
(0.00-0.01)\end{array}$ & 0.00 & $\begin{array}{l}0.18 \\
(0.16-0.18)\end{array}$ & $\begin{array}{l}3.08 \\
(2.89-3.33)\end{array}$ & $\begin{array}{l}0.14 \\
(0.00-0.27)\end{array}$ & $\begin{array}{l}0.12 \\
(0.10-0.13)\end{array}$ & $\begin{array}{l}0.27 \\
(0.24-0.29)\end{array}$ & $\begin{array}{l}0.71 \\
(0.29-1.51)\end{array}$ \\
\hline & PM10 & $\begin{array}{l}0.00 \\
(0.00-0.01)\end{array}$ & 0.00 & $\begin{array}{l}0.20 \\
(0.18-0.24)\end{array}$ & $\begin{array}{l}3.38 \\
(3.23-3.51)\end{array}$ & $\begin{array}{l}0.13 \\
(0.00-0.21)\end{array}$ & $\begin{array}{l}0.12 \\
(0.09-0.14)\end{array}$ & $\begin{array}{l}0.27 \\
(0.24-0.29)\end{array}$ & $\begin{array}{l}0.41 \\
(0.32-0.46)\end{array}$ \\
\hline & PM2.5 & $\begin{array}{l}0.01 \\
(0.00-0.01\end{array}$ & 0.00 & $\begin{array}{l}0.18 \\
(0.12-0.23)\end{array}$ & $\begin{array}{l}2.64 \\
(2.44-2.76)\end{array}$ & $\begin{array}{l}0.06 \\
(0.00-0.18)\end{array}$ & $\begin{array}{l}0.09 \\
(0.08-0.10)\end{array}$ & $\begin{array}{l}0.20 \\
(0.16-0.25)\end{array}$ & $\begin{array}{l}0.77 \\
(0.25-1.65) \\
\end{array}$ \\
\hline
\end{tabular}

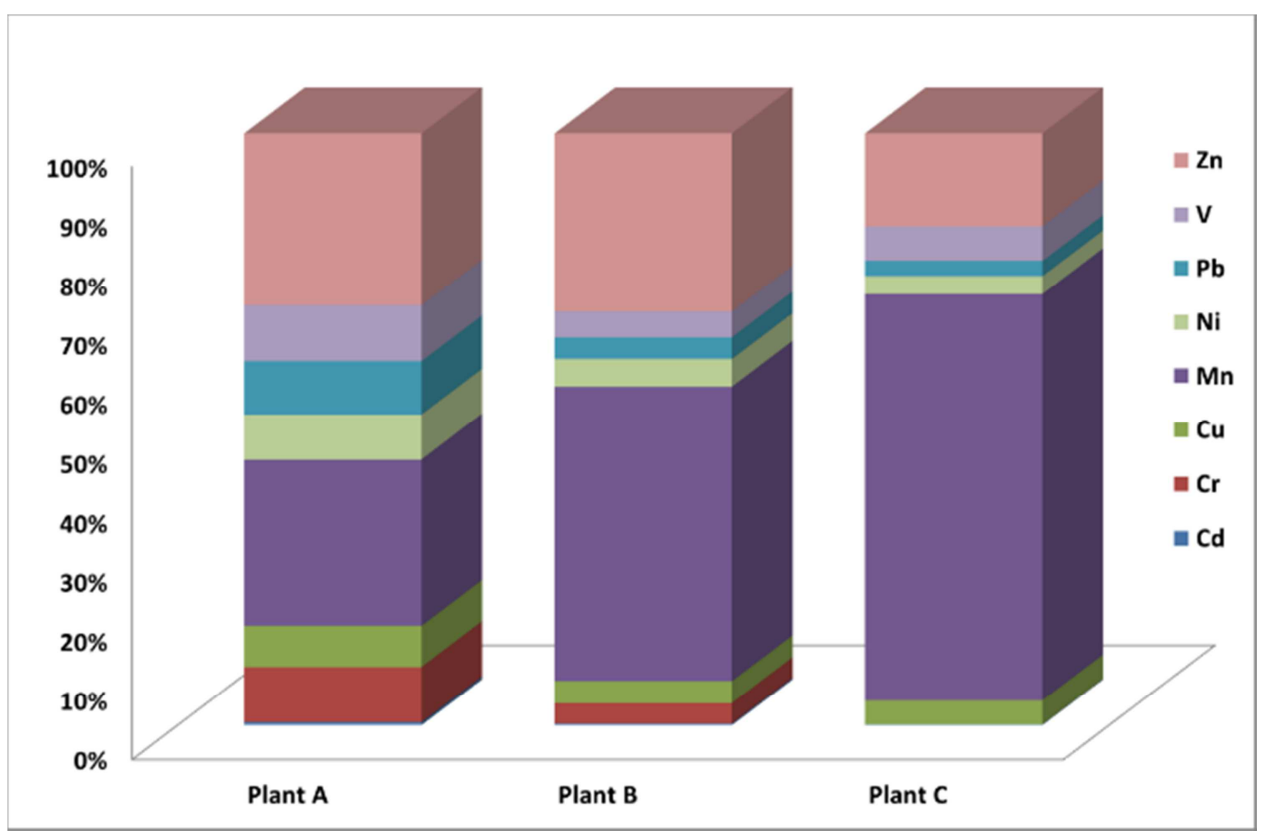

Figure 4. Distribution of heavy metal in TSP emitted from the stack of the tested plants.

\subsubsection{PM10}

The concentrations of heavy metal in PM10 differed among the plants (Table 2, Figure 5). The total concentration of heavy metals in PM10 for each plant was in the order Plant $\mathrm{A}>$ Plant B $>$ Plant C, as with TSP. In Plant A the order was $\mathrm{Mn}>\mathrm{Zn}>\mathrm{Cr}>\mathrm{Ni}>\mathrm{V}>\mathrm{Pb}>\mathrm{Cu}>\mathrm{Cd}$; in Plant $\mathrm{B}$ it was $\mathrm{Mn}>\mathrm{Zn}>\mathrm{V}>\mathrm{Pb}>\mathrm{Cu}>\mathrm{Ni}>\mathrm{Cr}>\mathrm{Cd}$, and in Plant $\mathrm{C}$ it was $\mathrm{Mn}>\mathrm{Zn}>\mathrm{V}>\mathrm{Cu}>\mathrm{Ni}>\mathrm{Pb}>\mathrm{Cd}>\mathrm{Cr}$. PM10 showed high concentrations of $\mathrm{Mn}, \mathrm{Zn}$ and $\mathrm{V}$, and low concentration of $\mathrm{Cd}$, as with TSP. The rankings for each of these compounds were somewhat different, possibly as a result of the difference in fuel used, as is the case of TSP. The distribution tendency of heavy metals in PM10 for each plant is similar to the distribution of heavy metals in TSP for each plant. However, in PM10 from Plant A, the concentration of Ni was higher than that of V, and in PM10 of Plant B the concentration of $\mathrm{Ni}$ was is slightly lower than that of $\mathrm{V}$, compared to TSP. That the difference in fuel affects the distribution of heavy metal, and these heavy metal can also be distributed differently depending on the particle size. 


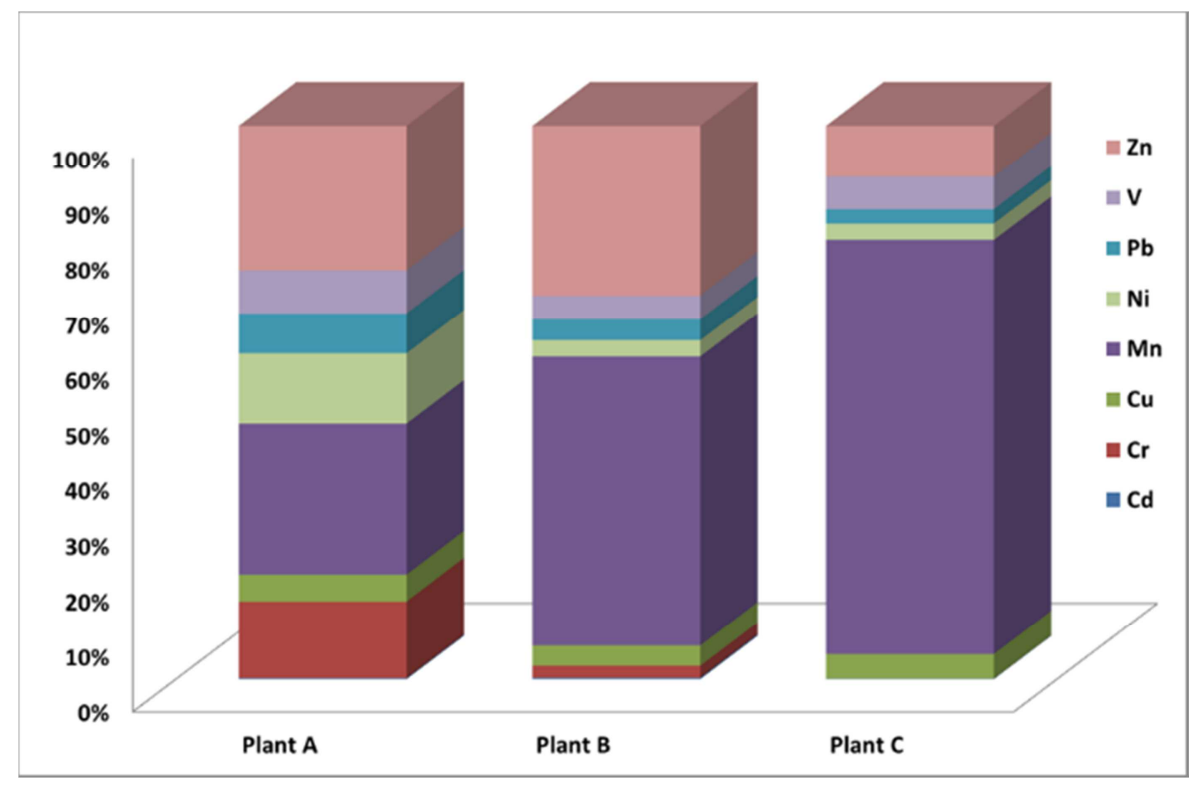

Figure 5. Distribution of heavy metal in PM10 emitted from the stack of the tested plants.

\subsubsection{PM2.5}

The concentrations of heavy metals in PM2.5 also differed among the plants (Table 2, Figure 6). The total concentration of heavy metals in PM2.5 for each plant was in the order Plant $\mathrm{A}>$ Plant $\mathrm{B}>$ Plant $\mathrm{C}$, as with TSP and PM10. Plant A the following was: $\mathrm{Zn}>\mathrm{Mn}>\mathrm{Cr}>\mathrm{Ni}>\mathrm{Cu}>\mathrm{V}>\mathrm{Pb}>\mathrm{Cd}$; in Plant $\mathrm{B}$ it was $\mathrm{Mn}>\mathrm{Zn}>\mathrm{V}>\mathrm{Pb}>\mathrm{Cu}>\mathrm{Ni}>\mathrm{Cr}>\mathrm{Cd}$, and in Plant $\mathrm{C}$ it was $\mathrm{Mn}>\mathrm{Zn}>\mathrm{V}>\mathrm{Cu}>\mathrm{Pb}>\mathrm{Ni}>\mathrm{Cd}>\mathrm{Cr}$.
The rankings for each of these compounds also differed, possibly as a result of differences in the fuel used, as in the cases of TSP and PM10. Although the tendency of distribution of heavy metal in PM2.5 is similar to that in TSP and PM10, Plant A showed the highest concentration of $\mathrm{Pb}$, and slightly higher $\mathrm{Zn}$ than Mn compared to TSP and PM10. The heavy metals seem to show different distribution tendencies by particle size.

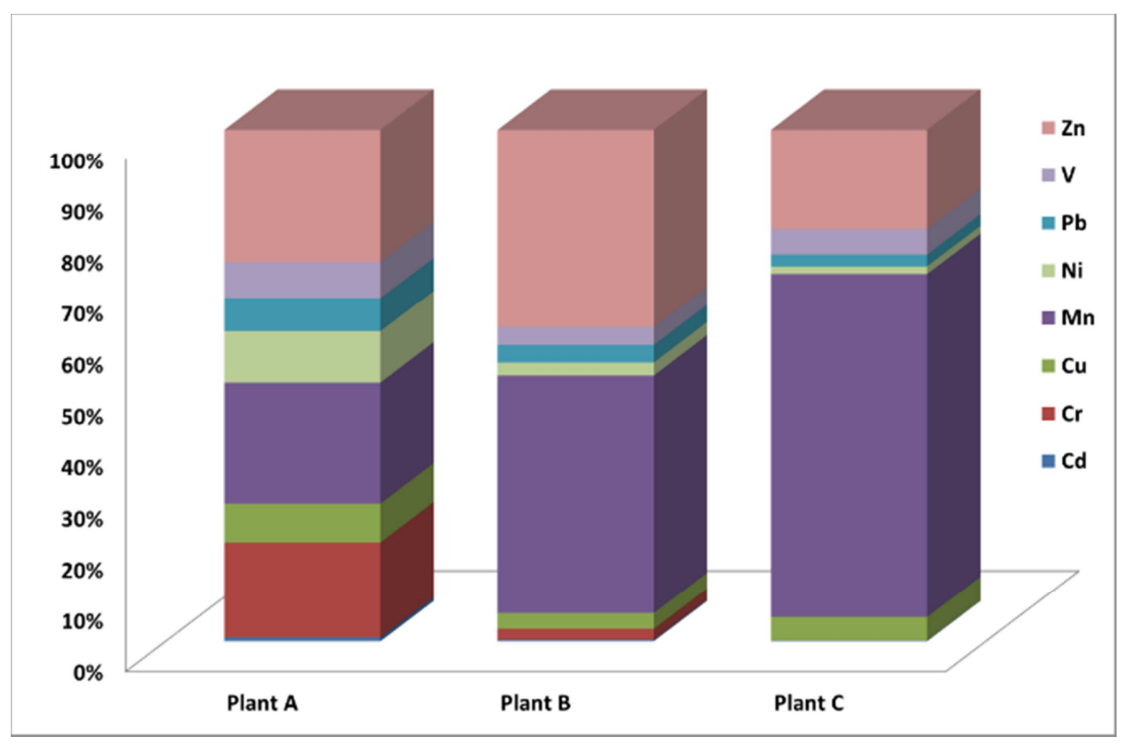

Figure 6. Distribution of heavy metals in PM2.5 emitted from the stack of the tested plants.

\section{Conclusion}

This study quantified the distributions of TSP, PM10 and PM2.5 and contents of heavy metals in those particles in emissions from three thermal power plants, which use the different fuel types and have the different electric-production capacities. The following conclusions were obtained.
(1) The emission concentration of TSP, PM10 and PM2.5 were affected by the type of fuel used and the electric generation capacity. These measurements were all higher in emissions from Plant A that uses heavy oil as the main fuel, than in emissions from Plant B that uses mainly anthracite, or in emissions from Plant $\mathrm{C}$ which uses mainly bituminous coal as fuel; the 
measurements were also higher in Plant B than in Plant C. The concentrations of particulate matter decreased as the electricity-generation capacity of the plant increased.

(2) The percentage of PM10 and PM2.5 to TSP differed among plants. The fraction of each particle size relative to the total concentration of particulate matter is the PM10 for TSP in the plant using bituminous coal. The fraction of PM2.5 was high. In the plants that use bituminous coal, the emissions of TSP were low, but had high proportions of PM10 and PM2.5. However, in the other plants, the emission of TSP was high had high proportions of PM10 and PM2.5. The efficiency of the electrostatic precipitator installed in each plant may be too low for removal of fine particles.

(3) The distribution of heavy metal by particle size of each plant was similar, but the distribution of heavy metals obviously differed among the plants. All of three measures of particulate matter were influenced by the fuel used. Therefore, the distribution characteristics of heavy metal according to particle size are different according to the type and amount of fuel used.

\section{Acknowledgements}

This work was supported by Korea Institute of Energy Technology Evaluation and Planning (KETEP) grant funded by the Korea government (MOTIE) (20161110100210, Development of AQCS solution for PM10 emission control for Korean Standard and New Standard Coal-fired Power Plants).

\section{References}

[1] Ministry of Environment (MEO), 2017. Framework Act on Environment Policy, Korea.

[2] Ministry of Environment (MEO), 2015(a). Annual Environmental Report, Korea.

[3] US EPA, 2012. National Ambient Air Quality Standards.

[4] European Environment Agency, 2008. Directive 2008/50 / EC.

[5] World Health Organization (WHO), 2005. Air Quality Guidelines for Particulate Matter, Ozone, Nitrogen dioxide and Sulfur dioxide.

[6] Katsouyanni K., Touloumi G., Samoli E., Gryparis A., Tertre A., Monopolis Y., Rossi G., Ballester F., Boumghar A., Anderson R., Wojtyniak B., Paldy A., Braunstein R., Pekkanen J., Schindler C. and Schwartz J., 2001. Confounding and effect modification in short-term effects of ambient particles on total mortality-results from 29 European cities within the APHEA2 project", Epidemiology, 12, 521-531.

[7] Cohen A and Ezzat M, 2004. Mortality impacts of urban pollution-Comparative quantification of health risks: global and regional burden of disease attributable to selected major risk factors, Geneva, World Health Organization, 1352-1434.

[8] Smith K. R., Veranth J. M., Hu A. A., Lighty J. S. and Aust A. E., 2000. Interleukin-8 levels in human lung epitkeial cells are increased in response to coal fly ash and vary with the bioavailability of iron, as a function of particle Size and source of coal, Chem. Res. Toxicol, 13, 118-125.

[9] Dockery O. W., Pope C. A. and Xu X., 1993. An association between air pollution and mortality in six U. S. cities, New England Journal of Medicine, 329, 1753-175.

[10] Health Effects Institute, 2000. Reanalysis of Harvard Six-Cities study and American Cancer Society study of particulate air pollution and mortality: A special report of the institute's epidemiology reanalysis project, Cambridge, MA.

[11] Pope C. A, Dockery M. L. and Long R. W., 2002. Lung cancer, cardiopulmonary mortality and long-term exposure to fine particulate air pollution, Journal of the American Medical Association, 287, 1132-1141.

[12] Jo S. Y., Sun W. Y. and Joung Y. W., 2012. PM2.5 abatement effect analysis Establish future management policy roadmap. Korean National Institute of Environmental Research, NIER N029280, National Institute of Environmental Research, Korea.

[13] http://sodac.nier.go.kr, 2014. Source of Emission Statistics, National Institute of Environmental Research, Korea.

[14] Smith I. M. and Sloss L. L., 1998. PM10/2.5-emission and effects. IEA coal research report, London.

[15] England G. C., Zielinska B. and Loss K., 2000. Characterizing PM2.5 emission profiles foe stationary source-comparison of traditional and dilution sampling techniques. Fuel Proce. Technol. 65-66, 177-188.

[16] Sloss L. L., 2004. The importance of PM10/2.5 emission. IEA Clean Coal Centre report, London.

[17] Soud H. N and Wu Z., 2000. East Asia-air pollution control and coal fired power generation. IEA coal research report, London.

[18] Ehrlich C., Noll G., Kalkoff W. D., Baumbach G. and Dreiseidler A., 2007. PM10, PM2.5 and PM1.0-Emissions from industrial plants-Results from measurement programmes in Germany. Atmospheric Environment 41, 6236-6254.

[19] Korean Standard Test Method (KSTM), 2015(b). ES 01112.1 Method for collecting particulate matter from exhaust gas, Ministry of Environment, Korea.

[20] Korean Standard Test Method (KSTM), 2015 (c). ES 01317.1a - Method for collecting fine dust (PM10 and PM2.5) in exhaust gas, Ministry of Environment, Korea.

[21] US EPA Method 201A, 2008. Determining PM10 and PM2.5 Emission from Stationary Source, USA.

[22] Ministry of Environment (MOE), 2015 (d). Air Environment Conservation Act, Korea.

[23] US EPA Method 3051A, 2007. MICROWAVE ASSISTED ACID DIGESTION OF SEDIMENTS, SLUDGES, SOILS, AND OILS, USA.

[24] US EPA Method 200.8, Revision 5.4, 1996. Determination of Trace Elements in Waters and Wastes by Inductively Coupled Plasma - Mass Spectrometry, USA. 
[25] Han J. S., Choi S. W., Kim J. E., Kim Y. L, Kim B. K., Hong T. G., Han K. B., Lee S. K. and Kim H. W., 2011. Environmental Test and Inspection QA/QC Handbook (2nd edition), NIER NO 2011-08-1294, National Institute of Environmental Research, Korea.

[26] Song G. J., Kyeong J. K., Moon Y. H., Joo J. H and Lee A. Y., 2009. A Study on the Establishing the Speciate of the Air Pollutants from Anthropogenic Sources in Korea (II), NIER-N022886, National Institute of Environmental Research, Korea.

[27] Han J. S., Jang K. W., Jung N., Kim H. C., Kim M. S., Song D. J., Kim S. K. and Hong J. Y., 2010. A Study on the Establishing the Speciate of the Air Pollutants from Anthropogenic Sources in Korea (III), NIER NO 2010-93-1268, National Institute of Environmental Research, Korea.

[28] Joung Y. W., Jeoun K. J., Han S. H, Uu M. K., Lee J. H., Kim H. L., An S. K., Kim B. J., Lee H, K., Lee T. H. and Kang J. W., 2013. A Study on the Speciation and the Control Measures of PM2.5 from Large Stationary Emission Source (I), NIER-SP2013-206, National Institute of Environmental Research, Korea.
[29] Joung Y. W., Jeoun K. J., Han S. H, Lee J. M., Song J. M., Kim H. L., Lee J. H., An S. K., Song M. S., Kyang S. M., Kim B. J. and Kim D. K., 2014. A Study on the Speciation and the Control Measures of PM2.5 from Large Stationary Emission Source (II), NIER-SP2014-206, National Institute of Environmental Research, Korea.

[30] Pio C. A., Nunes T. V., Borrego C. A., Martins J., 1989. Assessment of air pollution sources in an industrial atmosphere using principal component/multilinear regression analysis. Science of the Total Environment 80, 279-292.

[31] Pio C. A., Castro L. H., Cerqueira M. A., Santos I. M., Belchior F., Salgueiro M. L., 1996. Source assessment of particulate air pollutants measured at the south-west European. Atmospheric Environment 30, 3309-3320.

[32] Querol X., Viana M., Alstuey A., Amato F., Moreno T., Castillo S., Pey J., de la Rosa J., A. Sanchez A., Artinano B., Salvador P., Garcia Dos Santos S., Fernandez-Patier R., Moreno-Grau S., Negral L., Minguillon M. C., Monfort E., Gil J. I., Inza A., Ortega L. A., Santamaria J. M., Zabalza J., 2007. Source origin of trace elements in PM from regional background, urban and industrial sites of Spain. Atmospheric Environment 41, 7219-7231. 